\title{
EVOLUTION OF HIGHER EDUCATION: PROSPECTS - MODERNIZATION CONCEPTS
}

\author{
Yurii Safonov', Olga Galtsova², levgen Bazhenkov ${ }^{3}$
}

\begin{abstract}
The most popular international rankings on the development of higher education in Ukraine are presented, which show a mixed situation, namely that in some positions Ukraine is among the 50 countries with the strongest higher education systems in the world, but in the number of universities Ukrainian educational institutions are not leading. Analyzes the dynamics of the distribution of the number of students of higher educational institutions in Ukraine in accordance with the International Standard Classification of Education ISCED 2011. Also analyzed the dynamics of higher education institutions at the beginning of the 2019/20 academic year by subordination of institutions, the number of students in higher education institutions by source of funding. The main indicators of postgraduate and doctoral studies in Ukraine are given. The indicators of the number of foreign students in Ukraine are highlighted, the top 10 countries by origin of foreign students and the most popular universities among foreign students are provided. It is concluded that up to $50 \%$ of foreign students are trained in Ukraine in medical specialties, the training of foreign students in Ukrainian educational institutions is not only the image of the country, but also an important component of investment in the economy. Summarizing the current state and trends in the development of higher education in Ukraine, were identified current trends in the development of higher education and proposed a strategy for the development of higher education, which provides the maximum efficiency of all resources: organizational, institutional, instrumental, financial, scientific and methodological.
\end{abstract}

Key words: higher education, international rating, European Higher Education Area, higher education institutions, research activities, Ukrainian State Center for International Education.

JEL Classification: 120, 121, 125, 128

\section{Introduction}

Highly professional organization of education in any society is the key to the effective development of the state, as it provides an opportunity for citizens to develop through the training of highly qualified specialists. Modern higher education in Ukraine has been reforming for many years (Volkova, 2021). Since the signing of the Bologna declaration (2005), higher education has undergone significant changes, both in an attempt to improve the Bologna process and strengthen its market orientation. In the process of reform and implementation, problems arise, such as the lack of a balanced interaction between higher education and the mechanisms of labour market regulation.

Globalization processes are changing the nature and role of higher education in society, the influence of market relations in European higher education is increasing, providing a balanced interaction of higher education and the labor market, which is the key to effective and sustainable economic development. The COVID-19 pandemic significantly affected higher education, the national economy, which defined the boundary between education and the economy before and after the pandemic (Balakhtar, 2021). Today's dynamic changes in education, especially in higher education, require qualitative changes. Higher education reforms actualize the need for highly qualified creative teachers, specialists capable of implementing innovative methods and forms of learning, to carry out creative activities (Lypynskyi, 2000).

The modern system of quality assurance of higher education in Ukraine is formed under the influence

\footnotetext{
Corresponding author:

${ }^{1}$ State Scientific Institution "Institute of Education Content Modernization", Ukraine.

State Higher Educational Institution Kyiv National Economic University named after Vadym Hetman, Ukraine.

E-mail: sum1971@ukr.net

ORCID: https://orcid.org/0000-0001-5623-1965

${ }^{2}$ Classic Private University, Ukraine.

E-mail: olgagaltsova67@gmail.com

ORCID: https://orcid.org/0000-0003-0012-0371

${ }^{3}$ State Scientific Institution "Institute of Education Content Modernization", Ukraine.

E-mail: 1spartak@ukr.net

ORCID: https://orcid.org/0000-0003-0117-294X
} 
of world changes, particularly globalization and European integration (the needs of society in the development of uniform educational standards and quality control of services).

\section{Current research, problem analysis}

Changes in higher education, its development and formation became the subjects of dissertations, commemorative publications on the history of universities (Lypynskyi, 2000; Liapina, 2008; Liapina, 2009; Liapina, 2009)., some generalized works on the development of education and various studies on different issues based on the sources of the last century (Padun, 2002; Shekhovtseva, 2019; Burovytska, 2016).. In recent years, the organization and functioning of the market of educational services for the training of foreign students is given considerable attention by Ukrainian and foreign researchers: Kr. Bista, W. Teichler, O. Bilyk, A. Verbytska, M. Debych and others.

The purpose of the study is the analysis and dynamics of higher education development. The rationale for this study is to identify problems and propose a strategy for the development of higher education in Ukraine.

\section{Findings}

Higher education is integrated into the norms of the European system: modularity, selectivity of disciplines, etc. Every year the world compiles a ranking of the top 100 higher education institutions (HEIs), which helps applicants decide where to apply.

In the direction of Ukraine's integration from the European Higher Education Area (EHEA), a new list of specialties was introduced in 2015 (Pro zatverdzhennia pereliku haluzei znan i spetsialnostei), which should facilitate academic mobility of students and recognition of diplomas of Ukrainian HEIs. In order to bring the National Qualifications Framework in line with the European Qualifications Framework, a draft resolution of the Cabinet of Ministers of Ukraine "On Amendments to the Resolution of the Cabinet of Ministers of Ukraine from 23.11.2011 № 1341 (as amended by the Cabinet of Ministers of Ukraine from 12.06.2019 № 509)" was developed. Approved 142 standards of higher education (97 bachelor's, 45 master's), based on the competence approach and sharing the philosophy of determining the requirements for a specialist, which is the basis of the Bologna Process and the International Project of the European Commission "Harmonization of educational structures in Europe" (Perekhidna knyha MON za period z veresnia 2019 po cherven 2020). According to the Law of Ukraine "On Higher Education", the purpose of higher education is to obtain a high level of scientific (creative, artistic) professional and general competencies, which are necessary for activity in a particular specialty or in a particular field of knowledge (Pro vyshchu osvitu. Zakon Ukrainy vid 01.07.2014 № 1556-VII). The most significant changes were made to the Law of Ukraine "On Higher Education" in regard to the National Agency for Higher Education Quality Assurance (Stratehiia rozvytku vyshchoi osvity v Ukraini na 2021-2031 roky).

Higher education institutions (HEIs) in Ukraine provide the above levels of higher education depending on the type, namely: university, academy, institute, college (Stratehiia rozvytku vyshchoi osvity v Ukraini na 2021-2031 roky).

QS World University Rankings is the world's most popular university ranking, created for the convenience of students. The ranking is based on six key indicators: academic prestige (score $40 \%$ ), reputation among employers (10\%), student-to-faculty ratio (the better small-group teaching) (20\%), citation of research papers in Scopus (20\%), and proportion of international students and faculty $(5 \%+5 \%)$ (Stratehiia rozvytku vyshchoi osvity $\mathrm{v}$ Ukraini na 2021-2031 roky).

According to the rating of "The Good Country Index" (The Good Country), among 153 countries in 2020, Ukraine ranks 76th and Poland 31st. The attractiveness and stable demand for higher education is confirmed by the rate of knowledge-intensive employment (Global innovation index), where Ukraine in 2020 ranked 32nd with a rate of $37.7 \%$, and Poland -28 th place with $39.5 \%$, respectively.

In 2018, Ukraine entered the QS Higher Education System Strength Rankings (QS Higher Education System Strength Rankings), which determine the countries with the world's strongest higher education systems, where it ranked 44th out of 50 countries, ahead of Poland (46th). Ukraine received a score of 16.1 out of 100 on the "strength of the system" indicator. The index of accessibility of the higher education system in Ukraine is 14.4 out of 100 . The indicator "flagship university", which evaluates the work of the leading educational institution of the country in the QS World University Ranking (QS World University Ranking), included six Ukrainian universities, and Ukraine as a whole received a score of 8.5 out of 100 . The indicator "economic context" assesses the impact of national investment in higher education, and Ukraine has a score of 55.9 out of 100.

The U21 Ranking of National Higher Education Systems evaluates 50 national higher education systems according to 24 indicators (U21 Ranking of National Higher Education Systems). Of the 50 countries included in the 2020 ranking, Ukraine ranked $36^{\text {th }}$ with an index of 47.8 , improving its position from 2014 by 6 positions. Ukraine is followed by Poland, 32nd place (52.6). The Ukrainian higher education system has the highest positions in the module "resources", where 
it ranks 27th, the lowest - in the module "results" $\left(42^{\text {nd }}\right.$ place) (Stratehiia rozvytku vyshchoi osvity v Ukraini na 2021-2031 roky).

Analysis of the world rankings of higher education in Ukraine shows a mixed picture. For example, some positions place Ukraine among the 50 countries with the strongest higher education systems in the world, but there are only a few Ukrainian institutions in the world's leading university rankings that are not in the top positions.

Despite the new norms on university autonomy, in fact the HEIs did not acquire it. According to the EUA methodology, the level of autonomy is assessed by four components: academic, financial, organizational, and personnel. Unfortunately, Ukraine is not listed as a country in the EU autonomy ranking, but the ATHENA project conducted a study of the state of autonomy of Ukrainian universities in 2012-2015 (Avtonomiia universytetiv Ukrainy). The results showed that the legislative changes made some difference in the direction of increasing the level of organizational (from $44 \%$ to $68 \%$ ) and academic autonomy (from 51\% to 57\%). The level of organizational autonomy associated with the selection of the head, the criteria for his/her candidacy, the procedure for dismissal, the establishment of the term of office, as well as the right of the institution to invite non-employees to its governing bodies, remains low. With regard to academic autonomy, the weakness remains the institution's lack of authority to determine admission regulations. In terms of organizational autonomy Ukraine is close to Poland (67\%), in terms of academic autonomy it falls short of the level of Poland (68\%) and many other leading countries. They have the highest level of university autonomy in the staffing component (80\%), but the existing tariff schedule for public universities significantly reduces personnel autonomy (Stratehiia rozvytku vyshchoi osvity v Ukraini na 2021-2031 roky; Panych, 2019).

Summarizing information about the system of higher education in Ukraine since 2014. According to the State Statistics Service of Ukraine (State Statistics Service of Ukraine), during 2014-2020 there is a downward trend in all indicators (Table 1).
The number of university applicants decreased from 1689226 in $2014 / 2015$ to 1439706 in $2019 / 2020$. Thus, while in $2014 / 2015$ there were 664 institutions of higher education, in 2019/2020 there were 619 institutions of higher education (Stratehiia rozvytku vyshchoi osvity v Ukraini na 2021-2031 roky).

According to experts, "During the years 2021-2026, the number of school leavers is growing, and by 2031 it will be almost unchanged. We can expect an increase in the potential number of applicants. However, in 10 years, a new wave of decline in the number of graduates will begin, which creates additional risks for the long-term development of higher education" (Perekhidna knyha MON za period z veresnia 2019 po cherven 2020; Stratehiia rozvytku vyshchoi osvity v Ukraini na 2021-2031 roky; Panych, 2019).

Let's agree that the demographic crisis, given the age structure of Ukraine's population, and because it has a long-term impact, is one of the most significant risks to the higher education system, and the concept of lifelong learning has not gained traction among the population. Thus, the current trend threatens the reproduction of intellectual and professional capital and makes the process of innovative development impossible.

Difficulties with employment after graduation motivate many young people to enroll in foreign universities, as evidenced by the indicators they had before "educational emigration". In the period from 2008 to 2017, the number of Ukrainians who went abroad for higher education increased threefold, and the leading country was Poland. "Educational emigration" to Poland is associated with culture, close proximity and EU membership, relatively low prices, and job prospects (Education abroad: why Ukrainians go to Poland and Germany; Ukrainskyi tsentr otsiniuvannia yakosti osvity 2007-2020). Germany is also popular among Ukrainian students, and the main advantage is the quality of education and free tuition at state universities. Ukrainian students also go to Italy, the Czech Republic, the United States and Canada, but the growth rate is not very fast.

Insufficient number of high-tech industries, unclaimed specialties in natural and technical fields

Table 1

Distribution of the number of students of higher educational institutions in Ukraine in accordance with the International Standard Classification of Education ISCED 2011*

\begin{tabular}{|l|c|c|c|c|c|c|c|}
\hline \multicolumn{2}{|l|}{ Levels of education according to ISCED } & $2014 / 15$ & $2015 / 16$ & $2016 / 17$ & $2017 / 18$ & $2018 / 19$ & $2019 / 20$ \\
\hline The short-cycle higher education & 5 & 452292 & 427471 & 408732 & 398721 & 383710 & 355994 \\
\hline Bachelor's degree or equivalent & 6 & 890277 & 855683 & 800450 & 774076 & 746330 & 726336 \\
\hline Master's degree or equivalent & 7 & 346657 & 322116 & 377572 & 365768 & 392210 & 357376 \\
\hline Doctoral studies or equivalent & 8 & 3031 & 3008 & 2755 & 2632 & 2374 & 2658 \\
\hline
\end{tabular}

* Except for the temporarily occupied territory of the ARC, the city of Sevastopol, and parts of the territories in Donetsk and Luhansk regions Source: http://www.ukrstat.gov.ua/ 
(in 2020 Ukraine ranks $35^{\text {th }}$ in the Global Innovation Index / $25.3 \%$ of all graduates), in the TOP-10 directions applied for by applicants only two are informatics and none of the natural, engineering, technological directions for the development of the real economy (Ukrainskyi tsentr otsiniuvannia yakosti osvity 2007-2020). The unsatisfactory condition and raw-material orientation of the country's economy these factors lead to a distortion of the structure of the contingent of students, who have no guarantee of employment in the future, i.e., there is a gap between the number of trained specialists and the needs of the labour market. Almost $88.0 \%$ of HEIs in 2018 were self-employed.

"Some surveys, in particular, concerning the knowledge of job applicants, show employers' dissatisfaction with the level of knowledge and skills of job applicants. Employers consider the disconnection of theoretical knowledge from practice, unpreparedness to work in real business as a significant problem for all graduates" (Zvit za rezultatamy analitychnoho doslidzhennia). The problem is confirmed by the results of the Skills component of the Global Competitiveness Report 2019 (Global Competitiveness Index), which evaluates the level of training of the current workforce in the country, and the "skills" component ranked Ukraine $44^{\text {th }}$ with an index of 69.9. It should be noted that, according to official statistics, there is a high level of quality teaching staff of universities in Ukraine. In 2018, in the total number of teachers of universities, institutes, academies $48.7 \%$ were candidates, $11.6 \%$ were doctors of sciences, and $8.9 \%$ were professors (State Statistics Service of Ukraine).

The network of higher educational institutions in Ukraine is one of the densest: 6.7 HEIs and 8 colleges, technical colleges and schools per 1 million population. The dynamics of higher education institutions in Ukraine is shown in Table 2.

As of the beginning of 2019/2020, the number of HEIs increased by $1.4 \%$ compared to $2014 / 2015$, i.e., the network of HEIs as a whole is narrowing (Stratehiia rozvytku vyshchoi osvity $\mathrm{v}$ Ukraini na 2021-2031 roky). It should be noted that the introduction of market relations in Ukraine has led to the emergence of free private property, but the main supplier of higher education remains the state. This trend was primarily due to changes in the structure of the country's economy.

Since 2019, the strategy of the Ministry of Education and Science of Ukraine (MES) has been somewhat transformed, the Ministry transforms universities, unites, thereby stimulating increased funding (the new funding system should be a tool "to unite the universities"). The amount of funds depends on the demand for higher education and the number of students. This direction is designed to improve, in particular, the quality of higher education (U21 Ranking of National Higher Education Systems). The subordination of HEIs at the beginning of the 2019/20 academic year is given (Table 3 ).

A significant change in Ukraine, in the sphere of higher education, is the introduction of an approach to public funding of educational institutions in accordance with the results of their activities. Thus, the universities that, among other things, will have higher employment of graduates, will be able to receive more financial support and more international grants, will be included in the international rankings (Pro vyshchu osvitu. Zakon Ukrainy vid 01.07.2014 № 1556-VII; Stratehiia rozvytku vyshchoi osvity v Ukraini na 2021-2031 roky).

According to the current legislation, (Article 78 of the Law on Education of 05.09.2017 № 2145-VIII) "The state provides assignations for education in the amount of at least 7 percent of the gross domestic product from funds of the state and local budgets and other legal sources of funding" (Pro osvitu. Zakon Ukrainy st. 78 vid 05.09.2017 № 2145-VIII). The number of students at universities, depending on the sources of funding for their education, is shown in Table 4.

State expenditures on higher education as a percentage of state expenditures on education in Ukraine as a whole amount to $25 \%$ and correspond to the level of developed countries. As for the indicator of costs per student in Ukraine, in nominal terms, from 2015 to 2019 , they increased by more than one and a half times, but, given the devaluation of the national currency, they have decreased significantly. Since 2015, the number

Table 2

Dynamics of development of higher educational institutions in Ukraine

\begin{tabular}{|l|c|c|c|c|c|c|}
\hline \multicolumn{1}{|c|}{ Indexes } & $2014 / 15$ & $2015 / 16$ & $2016 / 17$ & $2017 / 18$ & $2018 / 19$ & $2019 / 20$ \\
\hline Number of institutions (total, units) & 664 & 659 & 657 & 661 & 652 & 619 \\
\hline Number of students (total, individuals) & 1689226 & 1605270 & 1586754 & 1538565 & 1522250 & 1439706 \\
\hline The number of people admitted to study (total) & 361110 & 323064 & 313856 & 323577 & 310326 & 297142 \\
\hline Number of students graduated from the HEIs (total) & 484482 & 447418 & 386668 & 421131 & 412914 & 383865 \\
\hline Number of students per 10,000 population* & 393 & 373 & 373 & 363 & 361 & 343 \\
\hline
\end{tabular}

*The estimated population is used in the calculation.

Source: http://www.ukrstat.gov.ua/ 
Table 3

Subordination of institutions of higher education at the beginning of the 2019/20 academic year

\begin{tabular}{|l|c|c|c|c|c|}
\hline \multicolumn{1}{|c|}{ Indexes } & $\begin{array}{c}\text { Number of } \\
\text { institutions, } \\
\text { units }\end{array}$ & $\begin{array}{c}\text { Number of } \\
\text { first-year } \\
\text { students }\end{array}$ & $\begin{array}{c}\text { Number of } \\
\text { students, } \\
\text { individuals }\end{array}$ & $\begin{array}{c}\text { The number } \\
\text { of graduates } \\
\text { of the HEIs, } \\
\text { individuals }\end{array}$ & $\begin{array}{c}\text { Number of scientific, } \\
\text { academic, and } \\
\text { pedagogical workers, } \\
\text { individuals }\end{array}$ \\
\hline TOTAL & $\mathbf{6 1 9}$ & $\mathbf{2 9 7 1 4 2}$ & $\mathbf{1 4 3 9 7 0 6}$ & $\mathbf{3 8 3 8 6 5}$ & $\mathbf{1 5 6 9 0 9}$ \\
\hline including: & 273 & 222663 & 1062472 & 281811 & 106620 \\
\hline $\begin{array}{l}\text { MINISTRY OF EDUCATION AND SCIENCE OF } \\
\text { UKRAINE }\end{array}$ & 1 & 846 & 3886 & 761 & 819 \\
\hline MINISTRY OF DEFENSE OF UKRAINE & 1 & 13 & 391 & 205 & 115 \\
\hline MINISTRY OF SOCIAL POLICY OF UKRAINE & 14 & 3487 & 15436 & 3905 & 3364 \\
\hline MINISTRY OF YOUTH AND SPORTS OF UKRAINE & 21 & 11831 & 69831 & 13769 & 13002 \\
\hline MINISTRY OF HEALTHCARE OF UKRAINE & 7 & 8014 & 35388 & 9448 & 2348 \\
\hline MINISTRY OF INTERNAL AFFAIRS OF UKRAINE & 1 & 209 & 1216 & 141 & 398 \\
\hline SECURITY SERVICE OF UKRAINE & 2 & 314 & 1033 & 315 & 104 \\
\hline $\begin{array}{l}\text { UKRAINIAN STATE CONSTRUCTION } \\
\text { CORPORATION "UKRBUD" }\end{array}$ & 184 & 28477 & 127321 & 36222 & 19425 \\
\hline OTHERS & 115 & 21288 & 122732 & 37288 & 10714 \\
\hline PRIVATE INSTITUTIONS & 11 & 2897 & 13781 & 4951 & 795 \\
\hline $\begin{array}{l}\text { including the CENTRAL UNION OF CONSUMER } \\
\text { ASSOCIATIONS OF UKRAINE }\end{array}$ & & \multicolumn{2}{|l|}{} \\
\hline
\end{tabular}

Source: http://www.ukrstat.gov.ua/

Table 4

Number of students in universities by source of funding for their education

\begin{tabular}{|l|c|c|c|}
\hline \multirow{2}{*}{\multicolumn{1}{|c|}{ Indexes }} & \multicolumn{3}{c|}{ Universities, academies, institutes } \\
\cline { 2 - 4 } & $2015 / 16$ & $2018 / 19$ & $2019 / 20$ \\
\hline Number of students, individuals & 1375160 & 1322324 & 1266121 \\
\hline including studying at the expense of the funds & 570043 & 534967 \\
\hline state budget & 649225 & 12834 & 2935 \\
\hline local budgets & 14722 & 6850 & 717293 \\
\hline legal entities & 9520 & 732597 & 42,3 \\
\hline individuals & 701693 & 43,1 & 0,9 \\
\hline Share of students (\%) studying at the expense of funds & 1,0 \\
\hline state budget & 47,2 & 0,5 & 0,2 \\
\hline local budgets & 1,1 & 55,4 & 56,6 \\
\hline legal entities & 0,7 & & \\
\hline individuals & 51,0 & \multicolumn{2}{c|}{} \\
\hline
\end{tabular}

Source: http://www.ukrstat.gov.ua/

of students studying at the expense of the state budget has decreased, for the period 2010-2018 the volume of state orders decreased by $41.8 \%$.

The Cabinet of Ministers of Ukraine has developed an innovative mechanism for distributing state budget expenditures among HEIs, implemented in 2020 (U21 Ranking of National Higher Education Systems). But, according to the author, the new mechanism does not contain a specific list of indicators of educational, scientific and international activities of universities, also there are no specific values (coefficients) for further adjustment of their funding.

The reduction of state orders weakens the position of regional universities, which due to political, economic and demographic instability can not count on an increase in the number of applicants, so there is an outflow of students to regional and metropolitan universities. Not meeting the requirements of employers and the quality of education, business refuses to fund the training of future specialists. In addition, in the context of falling incomes of the population, the undeveloped education lending market leads to the deterioration of the principle of accessibility of higher education. Reduced government spending challenges the fact that industry is a priority for the country.

The author agrees that "the indicative cost of higher education has been introduced to enable universities to bring tuition fees for certain specialties into line with real costs and to raise faculty salaries" (Postanova KMU "Deiaki pytannia zaprovadzhennia indykatyvnoi sobivartosti" vid 03.03.2020 № 191). Such initiatives do not correspond to the real state of 
solvency of the population, and universities constantly feel the lack of funds not only for development, but also for functioning in general.

The reduction in the number of universities led to a decrease in the magistral staff. The number of teaching and research faculty has decreased since $2014 / 2015$, but in $2019 / 2020$ compared to $2018 / 2019$, the number of employees in higher education increased by $0.4 \%$. A significant decrease in the number of applicants, as well as in the number of the magistral staff and the number of universities, academies, and institutes, was caused by the annexation of Crimea and military actions in the east of the country (Stratehiia rozvytku vyshchoi osvity v Ukraini na 2021-2031 roky). The low level of funding affects the financial situation of educators, i.e., there is a wage gap between the higher education sector and other sectors of the economy. Salaries of the magistral staff of higher education institutions in Ukraine are significantly lower than in the leading countries of the world. There is no incentive for research and innovation; all professional development costs become the educator's concern. "Low demand for pedagogical and scientific work by the state, low wages have led to a fall in the prestige of this activity. The rigid dependence of the staff schedule on the number of students also creates risks of employment of scientific and pedagogical workers and contributes to their migration" (Ukrainian Center for Educational Quality Assessment 2007-2020).

The unsatisfactory state of scientific-research work affects the activity of applicants at the scientific level. The number of HEIs that train postgraduate students decreased significantly (by $9.3 \%$ ), but the number of HEIs that train doctoral students increased (by 4.7\%). The main indicators of postgraduate and doctoral studies in Ukraine are shown in Table 5 and Table 6.

The instability of the number of institutions that train graduate students and doctoral candidates and have specialized boards is due to changes in the procedure for awarding degrees. Lack of social guarantees, low wages and lack of opportunities for self-fulfillment of scientists lead to an outflow of young people. The low efficiency of scientific research of universities lowers the rankings of Ukraine in relation to other universities of the world's leading countries, so the possibility of the presence of Ukrainian universities in the world's leading university rankings is small.

The XXI century is characterized by increasing globalization processes, which determine the transformation of all spheres of social life. Such modernization is also characteristic of the educational process of higher education, namely the internationalization of education, academic mobility, educational marketing, export/import of educational

Table 5

The main indicators of postgraduate education in Ukraine

\begin{tabular}{|c|c|c|c|c|c|}
\hline Indexes & 2015 & 2016 & 2017 & 2018 & 2019 \\
\hline $\begin{array}{l}\text { The number of research institutes and institutions of higher education that have } \\
\text { postgraduate programs, at the end of the year, units }\end{array}$ & 490 & 481 & 475 & 431 & 417 \\
\hline Number of postgraduate students at the end of the year, individuals & 28487 & 25963 & 24786 & 22829 & 25245 \\
\hline Number of people enrolled in graduate study per year & 9813 & 6609 & 7274 & 7172 & 7381 \\
\hline Number of graduate students per year & 7493 & 6703 & 6087 & 6401 & 2913 \\
\hline \multicolumn{6}{|l|}{ including with the defense of a thesis } \\
\hline individuals & 1958 & 1708 & 1438 & 1472 & 751 \\
\hline percent & 26,1 & 25,5 & 23,6 & 23,0 & 25,8 \\
\hline \multicolumn{6}{|l|}{ Scientific institutions } \\
\hline The number of institutions with postgraduate studies at the end of the year, units & 256 & 250 & 244 & 210 & 191 \\
\hline Number of graduate students at the end of the year, individuals & 3862 & 3125 & 2652 & 2080 & 2211 \\
\hline Number of people enrolled in graduate study per year & 1133 & 574 & 688 & 662 & 601 \\
\hline Number of graduate students per year & 1147 & 1014 & 951 & 852 & 330 \\
\hline \multicolumn{6}{|l|}{ including with the defense of a thesis } \\
\hline individuals & 140 & 125 & 110 & 99 & 56 \\
\hline percent & 12,2 & 12,3 & 11,6 & 11,6 & 17,0 \\
\hline \multicolumn{6}{|l|}{ Institutions of higher education } \\
\hline The number of institutions with postgraduate studies at the end of the year, units & 234 & 231 & 231 & 221 & 226 \\
\hline Number of graduate students at the end of the year, persons & 24625 & 22838 & 22134 & 20749 & 23034 \\
\hline Number of persons enrolled in graduate study per year & 8680 & 6035 & 6586 & 6510 & 6780 \\
\hline Number of graduate students per year & 6346 & 5689 & 5136 & 5549 & 2583 \\
\hline \multicolumn{6}{|l|}{ including with the defense of a thesis } \\
\hline individuals & 1818 & 1583 & 1328 & 1373 & 695 \\
\hline percent & 28,6 & 27,8 & 25,9 & 24,7 & 26,9 \\
\hline
\end{tabular}

Source: http://www.ukrstat.gov.ua/ 
Table 6

The main indicators of doctoral activity in Ukraine

\begin{tabular}{|c|c|c|c|c|c|}
\hline Indexes & 2015 & 2016 & 2017 & 2018 & 2019 \\
\hline $\begin{array}{l}\text { The number of research institutes and institutions of higher education that } \\
\text { have a doctoral programme, at the end of the year, units }\end{array}$ & 283 & 282 & 277 & 270 & 253 \\
\hline Number of doctoral students at the end of the year, individuals & 1821 & 1792 & 1646 & 1145 & 1113 \\
\hline Number of persons enrolled in doctoral studies per year & 650 & 584 & 493 & 544 & 511 \\
\hline Number of doctoral students per year & 563 & 551 & 543 & 963 & 511 \\
\hline \multicolumn{6}{|l|}{ including with the defense of a thesis } \\
\hline individuals & 169 & 153 & 153 & 232 & 143 \\
\hline percent & 30,0 & 27,8 & 28,2 & 24,1 & 28,0 \\
\hline \multicolumn{6}{|l|}{ Scientific institutions } \\
\hline $\begin{array}{l}\text { The number of research institutes and institutions of higher education that } \\
\text { have a doctoral programme, at the end of the year, units }\end{array}$ & 106 & 106 & 101 & 96 & 85 \\
\hline Number of doctoral students at the end of the year, individuals & 338 & 308 & 272 & 176 & 176 \\
\hline Number of persons enrolled in doctoral studies per year & 105 & 89 & 81 & 94 & 75 \\
\hline Number of doctoral students per year & 101 & 102 & 103 & 170 & 76 \\
\hline \multicolumn{6}{|l|}{ including with the defense of a thesis } \\
\hline individuals & 18 & 12 & 15 & 23 & 11 \\
\hline percent & 17,8 & 11,8 & 14,6 & 13,5 & 14,5 \\
\hline \multicolumn{6}{|l|}{ Institutions of higher education } \\
\hline $\begin{array}{l}\text { The number of research institutes and institutions of higher education that } \\
\text { have a doctoral programme, at the end of the year, units }\end{array}$ & 177 & 176 & 176 & 174 & 168 \\
\hline Number of doctoral students at the end of the year, individuals & 1483 & 1484 & 1374 & 969 & 937 \\
\hline Number of persons enrolled in doctoral studies per year & 545 & 495 & 412 & 450 & 436 \\
\hline Number of doctoral students per year & 462 & 449 & 440 & 793 & 435 \\
\hline \multicolumn{6}{|l|}{ including with the defense of a thesis } \\
\hline individuals & 151 & 141 & 138 & 209 & 132 \\
\hline percent & 32,7 & 31,4 & 31,4 & 26,4 & 30,3 \\
\hline
\end{tabular}

Source: http://www.ukrstat.gov.ua/

services, as well as the development of appropriate information and communication technologies. In this regard, the number of foreign students in the global market of educational services is growing rapidly (Londar, Shapovalova, Pron, 2020).

The processes of globalization also manifest themselves in the educational sphere, such as the growing number of foreign students. The presence of a large number of foreign students indicates a high rating of educational institutions and the quality of educational services.

Admission of foreigners and stateless persons to Ukraine in HEIs is carried out in accordance with the Laws of Ukraine "On Higher Education", "On the Legal Status of Foreigners and Stateless Persons", "On Foreigners of Ukrainian Origin”, "About Refugees And Persons In Need Of Additional Or Temporary Protection", Decree of the President of Ukraine of June 3, 1994 № 271 "On Measures for the Development of Economic Cooperation of the Oblasts of Ukraine with the Adjacent Regions of the Republic of Belarus and the Administrative-Territorial Units of the Republic of Moldova", Resolution of the Cabinet of Ministers of Ukraine No. 684 of September 11, 2013 "Issues of Employment of Foreigners and Stateless Persons", by the Order of the Ministry of Education and Science of Ukraine on November 1, 2013 № 1541 "Some issues of employment and training (internship) of foreigners and stateless persons", registered with the Ministry of Justice of Ukraine on November 25, 2013, № 2004/24536 (Londar, Shapovalova, Pron, 2020; Pro zatverdzhennia Umov pryiomu na navchannia do zakladiv vyshchoi osvity Ukrainy v 2020 rotsi).

Education of foreigners in Ukrainian universities is carried out in Ukrainian, Russian or English languages. Today in Ukraine there are about 400 HEIs, which train specialists for foreign countries and offer foreign students a wide range of specialties in various knowledge areas. The Ukrainian State Center for International Education (hereafter - USCIE) of the Ministry of Education and Science of Ukraine is the official state source of information on the training of foreign students. The State Enterprise "Ukrainian State Center for International Education" (abbreviated name - USCIE) is a state commercial enterprise and belongs to the Ministry of Education and Science of Ukraine (Ukrainian State Center for International Education).

The number of foreign students coming to Ukraine for higher education is constantly increasing. However, with the outbreak of hostilities in Ukraine, the number of foreign students began to decline, yet the peak was 
Table 7

The number of foreign students in Ukraine

\begin{tabular}{|l|c|c|c|c|c|c|}
\hline \multicolumn{1}{|c|}{ Indexes } & 2015 & 2016 & 2017 & 2018 & 2019 & 2020 \\
\hline Number of foreign students, total (individuals) & 63906 & 64066 & 66310 & 75605 & 80470 & 76548 \\
\hline The number of HEIs in Ukraine that educate foreign students & 185 & 228 & 269 & 443 & 455 & 394 \\
\hline
\end{tabular}

Source: http://www.ukrstat.gov.ua/

in 2019, when the number of foreign students reached 80 thousand, and in 2020 - more than 76 thousand. This is due to the COVID-19 pandemic, which has had a significant impact on higher education and the economy as a whole. The number of foreign students studying in Ukraine is given (Table 7).

The world market for educational services for foreigners is highly competitive and global. There is a risk of losing high positions on the world market due to the failure to make the necessary managerial and legislative decisions to ensure accessibility, as well as the creation of favorable conditions (Stratehiia rozvytku vyshchoi osvity v Ukraini na 2021-2031 roky).

Students come to Ukraine mainly from Asia (including Central Asia) and Africa. The level of secondary education in these countries is not always satisfactory, which creates certain problems in ensuring the quality of higher education for students. The promotion of Ukrainian universities in this market will strengthen the position of the country in the global educational system, as well as give stability to the system of higher education. The TOP-10 countries by origin of foreign students are given (Figure 1).

Today in Ukraine there are a large number of students from all over the world (about 155 countries). The interest in the education system in Ukraine is not surprising, there are educational institutions of different types: universities, academies, institutes, conservatories, colleges, etc. Besides, all of them can be both public and private. The most popular universities among international students are given (Figure 2).

Almost half of the foreign students, 39,841 more precisely, are studying medical professions in Ukraine. The average tuition fee for these majors is $\$ 4,300$ per year per student. For other majors, it is $\$ 2,000$. Taking into account almost 7,000 students in the preparatory division (average tuition fee is $\$ 1,500$ ) and more than 2,800 students in graduate studies and master's programs (average cost is $\$ 2,000$ ), international students are paying nearly $\$ 250$ million a year in tuition fees alone.

Education of foreign students in Ukrainian educational institutions is not only the image of the country, but also an important component of foreign investment in the economy. According to rough estimates, a foreign student receiving higher education in Ukraine spends at least $\$ 6,000-8,000$ a year.

The Ukrainian government seeks to increase the enrollment of foreign students at Ukrainian universities because foreign students training on a contractual basis and the cost of tuition fee for foreigners is twice as high as for Ukrainian citizens.

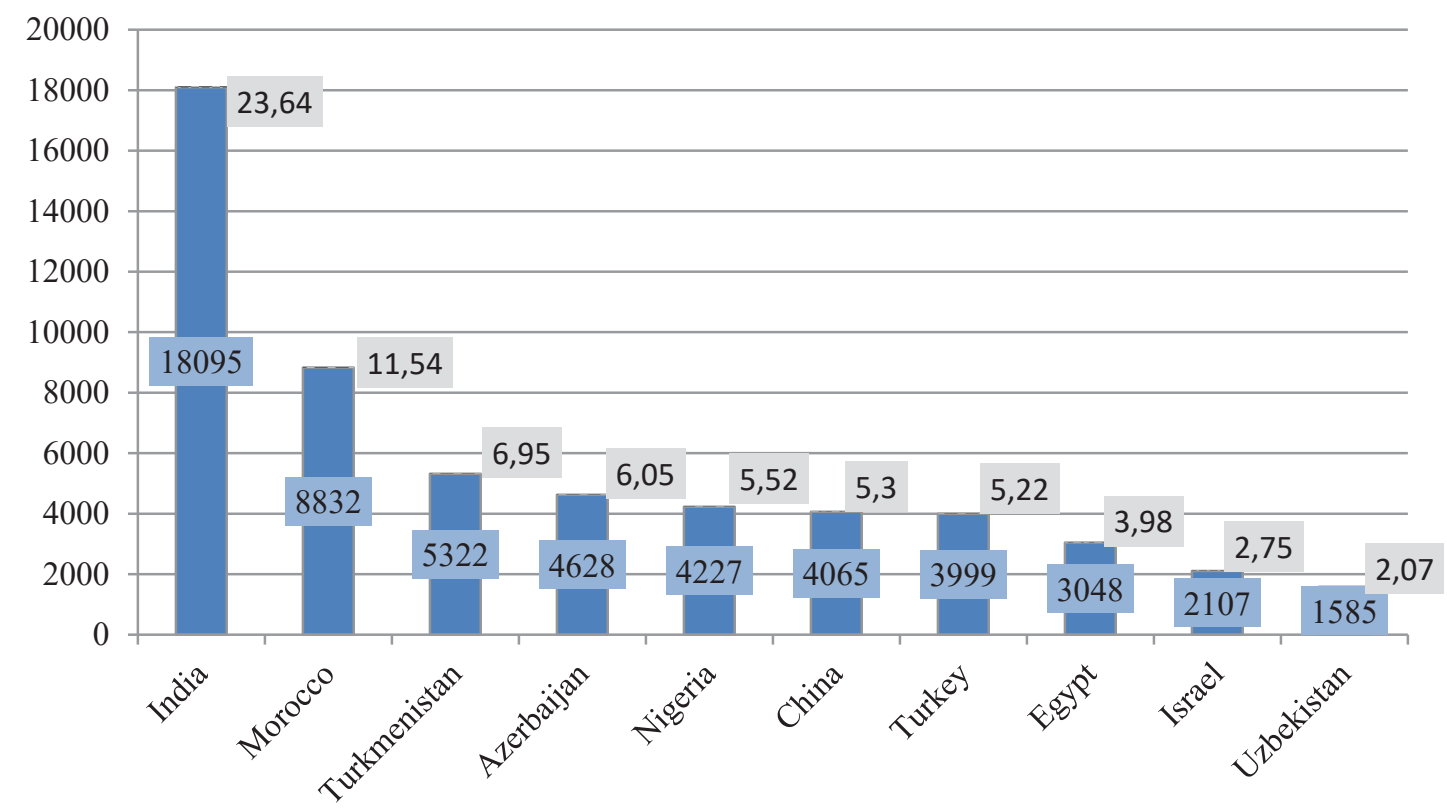

Figure 1. TOP-10 countries of origin of international students, individuals / \%

Source: http://www.ukrstat.gov.ua/ 


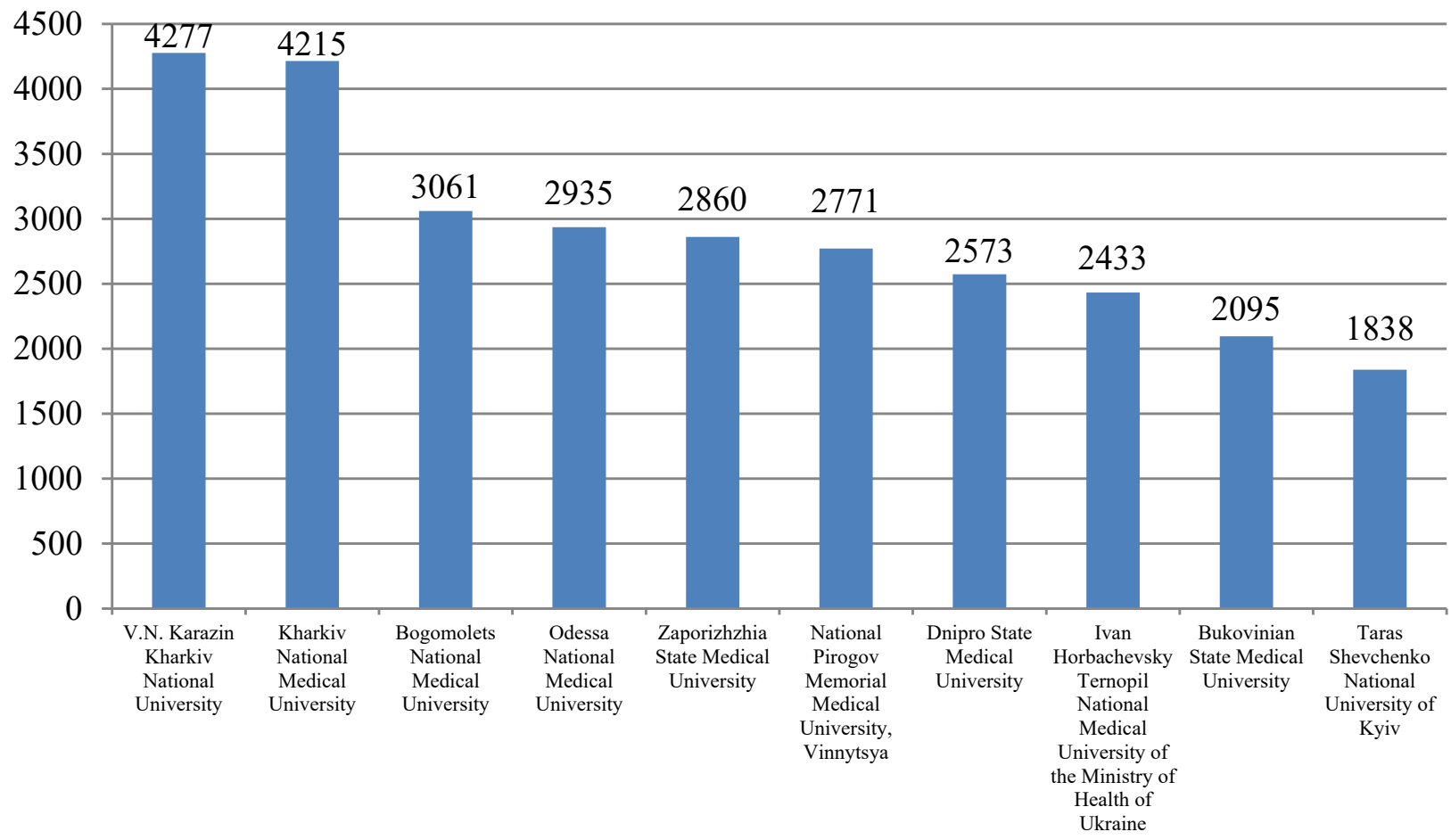

Figure 2. The most popular universities among international students, individuals

Source: http://www.ukrstat.gov.ua/

The government's desire to increase the number of international students is understandable, since international students are an important source of income. The funds that Ukraine receives from foreign students help maintain and even create workplaces in education, and allow the authorities of the universities where they study to invest money in improving the quality of educational services provided by national educational institutions to all students, regardless of citizenship (Inozemni studenty v Ukraini: osvita chy ekspluatatsiia?).

Summarizing the above, it can be highlighted the current trends in the development of higher education in Ukraine (Table 8).
Analyzing the current state and trends of development of higher education in Ukraine, it is necessary to identify priorities for solving problems that will meet today's challenges for the further development of higher education, proposing a strategy for the development of education (Figure 3).

\section{Conclusion}

The proposed strategy for the development of higher education in Ukraine provides, for condition of maximum efficiency, the use of all resources: organizational, institutional, instrumental, financial, scientific and methodological, etc.

Table 8

Trends in the development of higher education in Ukraine

\begin{tabular}{|l|l|}
\hline \multicolumn{1}{|c|}{ Advantages } & \multicolumn{1}{c|}{ Disadvantages } \\
\hline $\begin{array}{l}\text { Regulatory Affaires for higher education is close } \\
\text { to the European Higher Education Area }\end{array}$ & Low level of autonomy of higher education institutions \\
\hline Human capital & Unfavorable demographic situation \\
\hline Developed network of higher educational institutions & An increasing trend toward educational emigration \\
\hline \multirow{2}{*}{ The presence of world-class universities } & $\begin{array}{l}\text { Inconsistency between the structure of training to the current and future needs of } \\
\text { the labour market }\end{array}$ \\
\hline Higher education system. & The mismatch between the skills of freelance graduates and the needs of employers \\
\hline Attractiveness for international students & Low and inefficient financial support for higher education \\
\hline & The low prestige of teaching, the loss of human resources \\
\cline { 2 - 3 } & Weak connection of higher education institutions with science and business \\
\cline { 2 - 2 }
\end{tabular}


Vol. 7 No. 5, 2021

\begin{tabular}{|c|c|c|c|c|}
\hline Step 1 & Step 2 & Step 3 & Step 4 & Step 5 \\
\hline $\begin{array}{l}\text { Improvement of } \\
\text { the education } \\
\text { management } \\
\text { system }\end{array}$ & $\begin{array}{c}\text { Ensuring a } \\
\text { balanced labour } \\
\text { market }\end{array}$ & $\begin{array}{c}\text { Ensuring } \\
\text { access to } \\
\text { education for } \\
\text { different } \\
\text { segments of the } \\
\text { population }\end{array}$ & $\begin{array}{l}\text { Integration of science, } \\
\text { education and business }\end{array}$ & $\begin{array}{c}\text { Human } \\
\text { resource } \\
\text { development }\end{array}$ \\
\hline $\begin{array}{c}\text { Tasks: } \\
\text { Creation of } \\
\text { managerial } \\
\text { interaction } \\
\text { between MES } \\
\text { and HEIs; } \\
\text { Development of } \\
\text { autonomy; } \\
\text { Balancing the } \\
\text { network of } \\
\text { HEIs, taking } \\
\text { into account } \\
\text { sectoral and } \\
\text { regional } \\
\text { priorities; } \\
\text { Financial } \\
\text { stabilization. }\end{array}$ & $\begin{array}{l}\text { Tasks: } \\
\text { Forecasting the } \\
\text { need for } \\
\text { specialists in the } \\
\text { labour market; } \\
\text { Cooperation } \\
\text { between the } \\
\text { education system } \\
\text { and the labour } \\
\text { market. }\end{array}$ & $\begin{array}{l}\text { Tasks: } \\
\text { Building a } \\
\text { system of state } \\
\text { standards in } \\
\text { accordance } \\
\text { with the } \\
\text { content of the } \\
\text { strategic goals } \\
\text { of education; } \\
\text { Ensuring the } \\
\text { monitoring of } \\
\text { the quality of } \\
\text { education; } \\
\text { Logistics, } \\
\text { modernization } \\
\text { and } \\
\text { implementation } \\
\text { of innovative } \\
\text { technologies. }\end{array}$ & $\begin{array}{l}\text { Tasks: } \\
\text { Development of the } \\
\text { innovation ecosystem; } \\
\text { Improving the funding } \\
\text { and commercialization } \\
\text { of science; } \\
\text { Preparation of joint } \\
\text { projects of research } \\
\text { and academic } \\
\text { institutions. }\end{array}$ & $\begin{array}{l}\text { Tasks: } \\
\text { Enhancing } \\
\text { teacher status; } \\
\text { Stimulating the } \\
\text { professional } \\
\text { growth of } \\
\text { teachers. }\end{array}$ \\
\hline \multirow{2}{*}{\multicolumn{2}{|c|}{ RESULTS: }} & & & $\downarrow$ \\
\hline & & & Step 7 & Step 6 \\
\hline \multirow{2}{*}{\multicolumn{2}{|c|}{$\begin{array}{ll}\checkmark & \text { effective management system; } \\
\checkmark & \text { stability in financing the activities of } \\
\checkmark & \text { HEIs; } \\
\checkmark & \text { development of exploratory activities } \\
\checkmark & \text { of universities; } \\
\checkmark & \text { hising the rating of scientists; } \\
\checkmark & \text { balance in the labour market; } \\
\checkmark & \text { cessation of the outflow of students; } \\
\checkmark & \text { stable positive dynamics of HEIs. }\end{array}$}} & & $\begin{array}{l}\text { Integration into the } \\
\text { European and world } \\
\text { educational system }\end{array}$ & $\begin{array}{c}\text { The } \\
\text { development of } \\
\text { a system of } \\
\text { "lifelong } \\
\text { learning" }\end{array}$ \\
\hline & & & $\begin{array}{l}\text { Tasks: } \\
\text { Providing conditions } \\
\text { for integration; } \\
\text { Internationalization; } \\
\text { Attracting } \\
\text { international students. }\end{array}$ & $\begin{array}{l}\text { Task: } \\
\text { Implementing } \\
\text { the concept of } \\
\text { "lifelong } \\
\text { learning" }\end{array}$ \\
\hline
\end{tabular}

Figure 3. Strategy for the development of higher education in Ukraine

Source: created by the author

\section{References:}

Volkova, S. P. (2021). Vid universytetu do instytutu: reformuvannia vyshchoi osvity u 20-ti roky 20 stolittia na prykladi Katerynoslavskoho instytutu narodnoi osvity [From university to institute: reforming higher education in the 1920s on the example of the Ekaterinoslav Institute of Public Education]. Creative space, 1, 44-47. (in Ukrainian)

Balakhtar, K. S. (2021). Prohrama treninhu "rozvytok kreatyvnosti vykladachiv inozemnykh mov zakladiv vyshchoi osvity yak chynnyka yikh subiektyvnoho blahopoluchchia" [Training program "Development of creativity of foreign language teachers in higher education institutions as a factor of their subjective well-being"]. Bulletin of postgraduate education. Series: Social and behavioral sciences, 15, 10-33. (in Ukrainian)

Lypynskyi, V. V. (2000). Stanovlennia i rozvytok novoi systemy osvity v USRR u 20-i roky: monohrafiia [Formation and development of a new system of education in the USSR in the 20s: a monograph]. Donetsk: RVA Donetsk. State tech. univ., 247 p. (in Ukrainian)

Liapina, O. V. (2008). Instytuty narodnoi osvity (1920-ti - pochatok 1930-kh rr.): porivnialnyi aspekt Naddniprianska Ukraina: istorychni protsesy, podii, postati [Institutes of public education (1920s - early 1930s): a comparative aspect of the Dnieper Ukraine: historical processes, events, figures]: Coll. Science. Dnipropetrovsk Ave.: Dnipropetrovsk. nat. un-t, vol. 6, pp. 263-271. (in Ukrainian) 
Liapina, O. V. (2009). Stanovlennia instytutiv narodnoi osvity v URSR (persha polovyna 1920-kh rr.) [Formation of institutes of public education in the USSR (first half of the 1920s)] Gileya: scientific bulletin: coll. Science. Kyiv: Nat. ped. Univ. M.P. Dragomanova, 18, 56-65. (in Ukrainian)

Padun, S. (2002). Vykladannia istorychnykh dystsyplin u Katerynoslavskomu instytuti narodnoi osvity (1921-1933 rr.) [Teaching historical disciplines at the Ekaterinoslav Institute of Public Education (1921-1933)]. Bulletin of Dnipropetrovsk University. Series: history and archeology. Dnepropetrovsk: Dnepropetrovsk. Nat. Univ., 10, 314-319. (in Ukrainian)

Shekhovtseva, T. H. (2019). Interaktyvni metody navchannia yak osnova motyvatsii studentiv v umovakh suchasnoho pedahohichnoho protsesu [Interactive teaching methods as a basis for students' motivation in the modern pedagogical process]. Actual problems of modern medicine, t. 19, vol. 1, pp. 105-108. (in Ukrainian)

Burovytska, Yu. M. (2016). Informatsiino-komunikatsiini tekhnolohii u vyshchykh navchalnykh zakladakh: alhorytm vprovadzhennia [Information and communication technologies in higher educational institutions: implementation algorithm]. Bulletin of Chernihiv National Pedagogical University. Series: Pedagogical sciences, 133, 23-26. (in Ukrainian)

Bista Krishna (2018). International Student Mobility and Opportunities for Growth in the Global Marketplace. IGI Global. Available at: https://www.igi-global.com/book/international-student-mobility-opportunitiesgrowth/180922

Teichler Ulrich (2017). Internationalisation Trends in Higher Education and the Changing Role of International Student Mobility. Journal of international mobility, no. 1(5). Available at: https://www.cairn.info/ revue-journal-of-international-mobility-2017-1-page-177.htm/

Bilyk, O. M. (2016). Sotsializatsiia inozemnykh studentiv v osvitno-kulturnomu seredovyshchi vyshchoho navchalnoho zakladu Ukrainy: monohrafiia [Socialization of foreign students in the educational and cultural environment of a higher educational institution of Ukraine: monograph]. Kharkiv: Maidan, 336 p. (in Ukrainian)

Verbytska, A. V. (2018). Proekt natsionalnoi stratehii internatsionalizatsii vyshchoi osvity Ukrainy: intehrovana model [Draft National Strategy for Internationalization of Higher Education of Ukraine: Integrated Model]. Public administration: improvement and development, vol. 11. Available at: http://www.dy.nayka.com.ua/ pdf/10_2018/26.pdf (in Ukrainian)

Debych, M. A. (2019). Teoretychni zasady internatsionalizatsii vyshchoi osvity: mizhnarodnyi dosvid: monohrafiia [Theoretical principles of internationalization of higher education: international experience: monograph]. Nizhyn: P.E. Lysenko, 408 p. (in Ukrainian)

Pro zatverdzhennia pereliku haluzei znan i spetsialnostei, za yakymy zdiisniuietsia pidhotovka zdobuvachiv vyshchoi osvity: Postanova KMU vid 29.04.2015 № 266 [About the statement of the list of branches of knowledge and specialties on which preparation of applicants of higher education is carried out. Resolution of the Cabinet of Ministers of 29.04.2015 № 266]. Available at: https://zakon.rada.gov.ua/laws/show/266-2015-ח\#Text (in Ukrainian)

Perekhidna knyha MON za period z veresnia 2019 po cherven 2020 (2020) [Transitional book of the Ministry of Education and Science for the period from September 2019 to June 2020]. Ministry of Education and Science of Ukraine. Kyiv, 100 p. (in Ukrainian)

Pro vyshchu osvitu: Zakon Ukrainy vid 01.07.2014 № 1556-VII. [About higher education. Law of Ukraine of 01.07.2014 № 1556-VII]. Available at: https://zakon.rada.gov.ua/laws/show/1556-18\#Text (in Ukrainian)

Stratehiia rozvytku vyshchoi osvity v Ukraini na 2021-2031 roky (2020) [Strategy for the development of higher education in Ukraine for 2021-2031]. Ministry of Education and Science of Ukraine. Kyiv, 71 p. (in Ukrainian)

The Good Country. Available at: https: / / www.goodcountry.org/index/results/

Global innovation index. 2020 / World Intellectual Property Organization. Available at: https://www.wipo.int/ global_innovation_index/en/

QS Higher Education System Strength Rankings. Available at: https://www.topuniversities.com/system-strengthrankings/

QS World University Ranking. Available at: https://www.topuniversities.com/university-rankings/worlduniversityrankings/

U21 Ranking of National Higher Education Systems. Available at: https://universitas21.com/network/u21open-resourcesand-publications/u21-rankings/u21-ranking-national-higher-education

Avtonomiia universytetiv Ukrainy: analiz i plan dii / Asotsiatsiia Yevropeiskykh Universytetiv 2012-2015 [Autonomy of Ukrainian universities: analysis and action plan / Association of European Universities 2012-2015]. Available at: http://www.athena-tempus.eu/images/docs/Translations/04_scorecard.pdf (in Ukrainian)

Panych, O. (2019). Universytetska avtonomiia v konteksti ukrainskoho zakonodavstva i praktyky [University autonomy in the context of Ukrainian legislation and practice]. Educational policy. Available at: http://educationua.org/ua/component/content/article/12-articles/1348-universitetska-avtonomiya-vkonteksti-ukrajinskogozakonodavstva-i-praktiki?fbclid=IwAR1KXTJkiWI1VbzOk7BQj-urpblXrbLhJg7x31Kx7UN_Vv796ZX7strlKNo (in Ukrainian)

State Statistics Service of Ukraine. Website. Available at: http://www.ukrstat.gov.ua/ (in Ukrainian)

Education abroad: why Ukrainians go to Poland and Germany. Available at: http://www.theinsider.ua/ lifestyle/55d6d2752bfc6/ (in Russian) 
Ukrainskyi tsentr otsiniuvannia yakosti osvity 2007-2020 [Ukrainian Center for Educational Quality Assessment 2007-2020]. Available at: http://testportal.gov.ua (in Ukrainian)

Zvit za rezultatamy analitychnoho doslidzhennia. Znannia ta navychky vypusknykiv yurydychnykh fakultetiv ta zakladiv vyshchoi osvity cherez pryzmu vidpovidnosti potrebam rynku pratsi [Report on the results of analytical research. Knowledge and skills of graduates of law faculties and institutions of higher education through the prism of compliance with the needs of the labor market]. Available at: https://uba.ua/documents/ ZVIT Jurosvita.pdf (in Ukrainian)

Global Competitiveness Index. Available at: http://www3.weforum.org/docs/WEF_TheGlobalCompetitiveness Report2019.pdf

Pro osvitu: Zakon Ukrainy st. 78 vid 05.09.2017 № 2145-VIII [About education. Law of Ukraine Art. 78 dated 05.09.2017 № 2145-VIII]. Available at: https://kodeksy.com.ua/pro_osvitu/78.htm (in Ukrainian)

Pro rozpodil vydatkiv derzhavnoho biudzhetu mizh zakladamy vyshchoi osvity na osnovi pokaznykiv yikh osvitnoi, naukovoi ta mizhnarodnoi diialnosti: Postanova KMU vid 24.12.2019 r. № 1146 [On the distribution of state budget expenditures between higher education institutions based on indicators of their educational, scientific and international activities. Resolution of the Cabinet of Ministers of 24.12.2019 № 1146]. Available at: https://zakon.rada.gov.ua/laws/show/1146-2019-п\#Text (in Ukrainian)

Postanova KMU "Deiaki pytannia zaprovadzhennia indykatyvnoi sobivartosti" vid $03.03 .2020 \quad № 191$ [Resolution of the Cabinet of Ministers of Ukraine "Some issues of introduction of indicative cost" from 03.03.2020 № 191]. Available at: http://search.ligazakon.ua/1_doc2.nsf/link1/KP200191.html (in Ukrainian)

Ukrainian Center for Educational Quality Assessment 2007-2020. Website. Available at: http://testportal.gov.ua (in Ukrainian)

Londar, S. L., Shapovalova, O. O., \& Pron, N. B. (2020). Rynok osvitnikh posluh v Ukraini: konkurentni perevahy ta suchasni vyklyky dlia inozemnykh studentiv [The market of educational services in Ukraine: competitive advantages and modern challenges for foreign students]. Educational analytics of Ukraine, 1(8), 5-22. (in Ukrainian)

Pro zatverdzhennia Umov pryiomu na navchannia do zakladiv vyshchoi osvity Ukrainy v 2020 rotsi: Nakaz Ministerstva osvity i nauky Ukrainy vid 11.10.2019 № 1285 [On approval of the Terms of admission to higher education institutions of Ukraine in 2020. Order of the Ministry of Education and Science of Ukraine dated 11.10.2019 № 1285]. Available at: https://zakon.rada.gov.ua/laws/show/z1192-19 (in Ukrainian)

Ukrainian State Center for International Education. Website. Available at: https://studyinukraine.gov.ua/ (in Ukrainian)

Ministry of Education and Science of Ukraine. Website. Available at: https://mon.gov.ua (in Ukrainian)

Inozemni studenty v Ukraini: osvita chy ekspluatatsiia? [International students in Ukraine: education or exploitation?]. Available at: http://www.euroosvita.net/prog/print.php/prog/print.php?id=1808 (in Ukrainian) 